DELEGATES from the contracting parties to the London Dumping Convention 1972, along with observers from other countries and interested international organisations, met for the first time last month in London to choose an appropriate organisation to undertake its secretariat duties and to begin preparations for its first substantive meeting later this year.

The world-wide Convention-its full title is the Convention on the Prevention of Marine Pollution by Dumping of Wastes and Other Matter, London 1972-has been signed by 54 states, 22 of which have ratified it. The Convention prohibits the dumping at sea of certain dangerous substances, including mercury and cadmium and their compounds, organohalogen compounds and highly radioactive materials, and subjects the dumping of a large number of other substances to stringent control by the issue of specific permits by national authorities.

The conference agreed to a joint proposal from Britain and Mexico that the secretariat's work should be given to the Inter-Governmental Maritime Consultative Organisation (IMCO), the London-based UN agency with over 90 members which has until now administcred conventions regarding marine pollution from ships and operated in the fields of marine safety and navigation.

The conference set up a working committee to examine the plan, and also agreed that the first substantive meeting of contracting parties to the Convention should be held in September.

- The enforcement from the beginning of January of further provisions of the Control of Pollution Act 1974, which covers waste disposal and reclamation, noise, water and air pollution, has coincided with the Department of the Environment's latest survey revealing a further slight fall in the extent to which the UK's rivers and canals are polluted.

A total of 840 miles of river and canal is now classed as "grossly polluted", a reduction of 46 miles. The improvement has increased marginally the lengths of river classed as "poor quality requiring urgent improvement", but at the other extreme an extra 160 miles have been added to the lengths considered free from pollution.

The survey is based on tests carried out in 1973. The improvement on the previous survey in 1972-the first was made in 1970-was less marked in tidal rivers and canals than in nontidal rivers. And altogether a total of 182 miles was downgraded.
- The reports of three separate committees examining lead levels in food were published last month when the Working Party on the Monitoring of Foodstuffs for Heavy Metals carried in its fifth report (Survey of Lead in Food: First Supplementary Report) two appendices containing the advice of the Food Additives and Contaminants Committee and of the

\section{Around Britain}

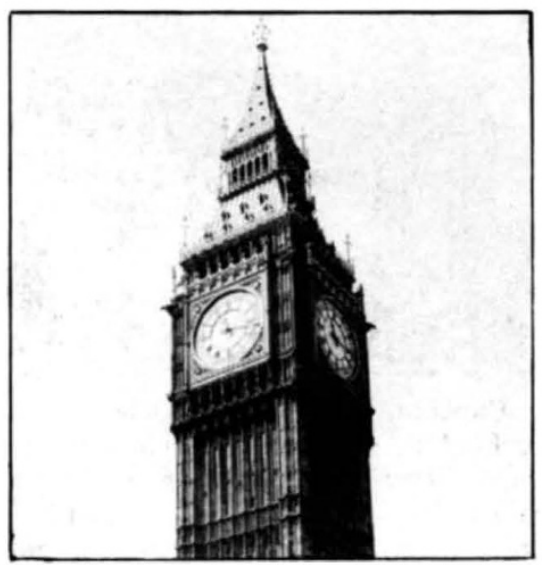

toxicity sub-committee of the Committee on Medical Aspects of Chemicals in Food and the Environment.

The Working Party, whose second report, in 1972, was also a survey of lead in food, concluded that the amounts of lead in the average diet in the UK had not increased since then, and that the mean lead concentration in canned infant foods had significantly decreased. The toxicity sub-committee, which advises the Food Additives and Contaminants Committee and various government departments on the toxicological aspects of the use or presence of additives and pollutants in food and the environment, considered that the present intake of lead from food in the UK was unlikely to constitute a hazard to the health of the general population.

The Working Party's surveys, involving the analysis of some 6,000 samples of foodstuffs and nearly 12,000 samples of drinking water, showed that the average consumer's lead intake was less than half the 'provisional tolerable weekly intake' of $3 \mathrm{mg}$ for adults, published by the $\mathrm{FAO} / \mathrm{WHO}$.

But the Food Additives and Contaminants Committee, although endorsing the underlying $\mathrm{v}$ i e w, recommended reductions in the maximum permitted amounts of lead in food in its separately published Review of the Lead in Food Regulations. Margins of safety were not as great as could be desired, the committee argued. It wanted ministers to enforce a limit of one part per million for most foods, a lower limit for baby foods, an end to the exemption from all limits of fish in which lead occurs naturally, and extra efforts to cut the amounts of lead in tinned foods.

- Just a couple of weeks after the announcement that Lord Beswick would head the new publicly owned corporation British Aerospace when it is formed-an appointment that attracted some Opposition criticism because he has not held an executive position of any sort in industry - the Labour Government named the board members of the new British National Oil Corporation (BNOC) whose first task will be to organise the structure of the state oil undertaking. And on the list so far is not a single senior oil industry management executive.

Indeed, the only man with any remotely practical experience in the area seems to be $\mathrm{Mr}$ Denis Rooke, chairman-designate of the British Gas Corporation. But his appointment, like that of the chief executive of the Shetland Island Council, drew speculation about conflicts of interest as well as about BNOC's possible influence over British Gas. And the inclusion of Lord Balogh as deputy chairman, a part-time post, has raised questions about BNOC's independence from government interference, because although he has retired as Minister of State at the Department of Energy (headed by $\mathrm{Mr}$ Anthony Wedgwood Benn), Lord Balogh remains $\mathrm{Mr}$ Benn's special adviser.

The chairman of the board, which also includes a lawyer, a trade union leader and several civil servants, is Lord Kearton, formerly head of Courtaulds.

- Dr Walter Marshall, the Director of Harwell, the Atomic Energy Research Establishment, is relinquishing his position (though not, apparently, his office) there to become deputy chairman of the UK Atomic Energy Authority (UKAEA) on Mr Frank Doggert's retirement. Hc will retain his other major post, that of chief scientific adviser to the Department of Energy, except when it comes to nuclear matters, which are the province of the UKAEA chairman, Sir John Hill.

The move, announced by Mr Benn, marks a large promotion. $\mathrm{Dr}$ Marshall was, at 43 , the most junior member of the UKAEA Board; he now has responsibility for scientific and technical policy throughout the organisation. Dr Lewis Roberts will take his place as director of Harwell. 